\title{
TITLE:
}

\section{EUDISTOMA LAYSANI (SLUITER) FROM THE GULF OF THAILAND}

\section{$\operatorname{AUTHOR}(\mathrm{S})$ :}

Senawong, Chokechai

\section{CITATION:}

Senawong, Chokechai. EUDISTOMA LAYSANI (SLUITER) FROM THE

GULF OF THAILAND. PUBLICATIONS OF THE SETO MARINE BIOLOGICAL LABORATORY 1972, 19(6): 427-430

\section{ISSUE DATE:}

1972-03-31

URL:

http://hdl.handle.net/2433/175735

\section{RIGHT:}




\title{
EUDISTOMA LAYSANI (SLUITER) FROM THE GULF OF THAILAND' ${ }^{1)}$
}

\author{
Сhokechat SENAWONG
}

Seto Marine Biological Laboratory

With 1 Text-figure

Several colonies of a synascidian were collected in October, 1970 by a student of Kasetsart University, Bangkok, while he was studying the invertebrate fauna in Petra Bay, a small bay of Rayong Province on the southeastern coast of the Gulf of Thailand. The colonies were submitted to me by courtesy of Mr. Weerayudth Lauhajinda, an instructor of the Biology Department of that university, for identification at the Seto Marine Biological Laboratory. According to the collector, this synascidian was found attaching to small boulders or pebbles on the muddy-sand beach at the lower level of the intertidal area partly protected by a small island. All the specimens were preserved in formalin. The colonies resemble Distoma laysani Sluiter, 1900 described from Laysan, the Hawaiian Islands, and reported later from the Siboga area (Sluiter, 1909) and the Palau Islands (ToкıокA, 1967) and the form from Iwayama Bay, the Palau Islands, identified by Tokioka (1942) with Eudistoma olivaceus (VAN NAME) of the West-Indies, especially more closely the former. However, the original description of $D$. laysani is not complete and Tokioks's supplementary description is based on only a single colony. Thus, the present description is prepared to confirm the specific character of this species.

I am much indebted to Dr. T. Tokioka of the Seto Marine Biological Laboratory for identification, to whom my hearty thanks are due. Also I am very grateful to $\mathrm{Mr}$. LAUHAJINDA for his kindness in sending the specimens to me and in informing me the details of the habitat and coloration of living specimens as he was told by his student.

\section{Description}

Colony: Four colonies in the material. They consist each of the common basal mass and cormidia, about $25 \mathrm{~mm}$ in thickness of the common basal mass and the smallest and biggest colonies are $25 \mathrm{~mm}$ and $60 \mathrm{~mm}$ in diameter respectively. The smallest colony bears 9 cormidia, while the biggest has up to 58 ones inclusive of some very

1) Contributions from the Seto Marine Biological Laboratory, No. 562.

Publ. Seto Mar. Biol. Lab, XIX (6), 427-430, 1972. (Article 28) 
small cormidia containing only a few zooids. Number of zooids per cormidium varies with the size of the cormidium, for instance from 3 or 4 zooids in very small ones to 30 or more in big ones. In 3 colonies, most of the cormidia are strongly contracted, and only one colony is found in an extended state (fig. 1, A). Many cormidia are divided distally into 2 finger-like tips; one of the largest cormidia is $12 \mathrm{~mm}$ long and
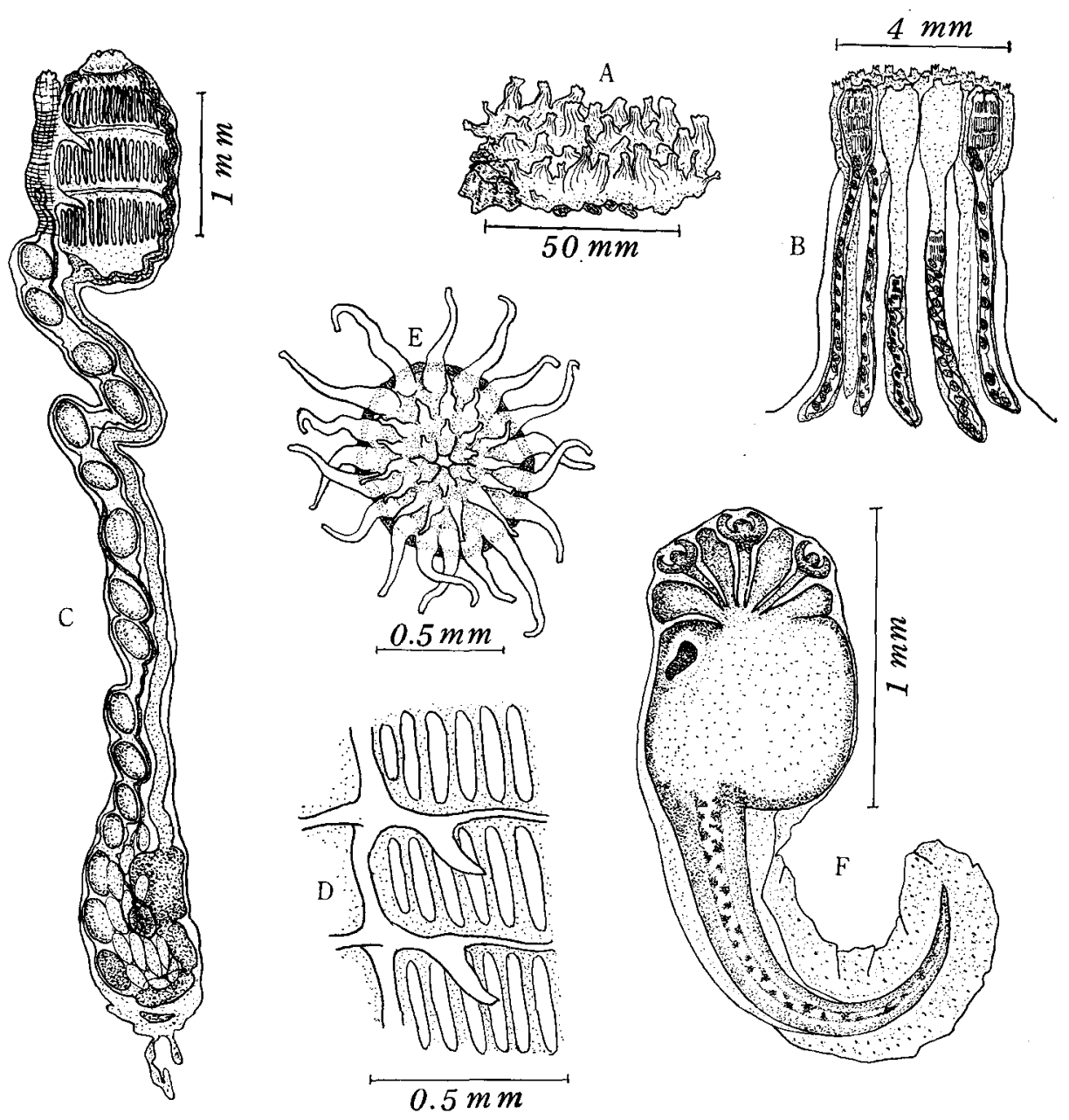

Fig. 1. Eudistoma laysani (Slutter). A) A colony. B) A cormidium. G) Zooid from the right side. D) Dorsal languets. E) Three orders of tentacular rings. F) An embryo.

$7 \mathrm{~mm}$ in diameter. The corona is soft and quite free from any encrusting materials, some with several thoracic chambers wholly empty because of contraction of zooids down to the middle or basal part of the peduncle (fig. 1, B). The corona is slightly brownish-yellow in the living state, but becomes paler in preserved specimens. The peduncle is grayish and rather transparent, many abdomens of zooids are seen through 
the pellicle. The common basal mass is extended widely, covered with harder pellicle, and impregnated with many faecal pellets in some parts. In preserved specimens, the common basal mass is grayish olive in color, but it is a little more greenish in living ones.

Zooid: Some small zooids are only $4 \mathrm{~mm}$ long, while big zooids may reach $15 \mathrm{~mm}$ in an extended state, though most of examined zooids are about $7-8 \mathrm{~mm}$ in a slightly contracted state (fig. 1, C). The thorax is usually $1.5 \mathrm{~mm}$ long and about $1 / 5$ to $1 / 6$ as long as the abdomen. Both the branchial and atrial apertures are 6 lobed, the latter forms a significantly long siphon (fig. 1, C). The abdomen is formed by a long but narrow intestinal loop and in most cases is extended down to anchor in the common basal mass.

Thorax: Transverse muscles are very fine, approximately 30-35 in number; longitudinal muscles about 20 on each side. Stigmata elongate, and about 15 ones are seen in each of 3 rows. Two transverse vessels are seen in the branchial sac, together with 2 dorsal languets slightly displaced to the left side from the dorso-median line by 2-3 stigmata (fig. 1, D). Dorsal tubercle almost round and prominent; ciliated groove small and oval in shape. There are usually 16-20 large tentacles, but may be up to about 40 when small and minute ones are included (fig. 1, E). Frequently, one embryo or one embryo and a fertilized egg are seen incubated in the cloacal chamber; and 2 embryos may be seen only in a few zooids.

Abdomen: The long thin-walled oesophagus leads to the stomach with much thickerwall and smooth surface, globular in shape, whitish, and situated almost at the posterior end of the abdomen. The hind-stomach is smaller, thick-walled, smoothsurfaced and whitish. The midintestine is constricted off from the hind-stomach and laid at the posterior end of the abdomen. The rectum is constricted off from the short midintestine, too, but without forming any caecum there. Usually it contains many faecal pellets. The anus is small, bilobed and opens at the level of the second transverse vessel. The faintly yellowish ovary and many testicular follicles are enclosed with in the intestinal loop, the former at the level of the pyloric end of the stomach and the latter in the distal part of the loop.

Embryo: The trunk is oval and about $1 \mathrm{~mm}$ in length; the tail is a little longer than the trunk (fig. 1, F). Three cup-shaped adhesive papillae are arranged lineally and four pairs of ampullae are defined at the anterior portion of the trunk.

Remarks: The colonies from the Gulf of Thailand conform well to the colony of Eudistoma laysani (Sluiter) described by Tokioka from the Palau Islands (1967, pp. 119-121), but differ from it in number of branchial tentacles, which is given as 16 by Sluiter (1900) and as 16 (?) by Tokioka. Much smaller number given by these authors is evidently due to a strongly contracted state of their specimens. The existence of up to 40 tentacles in the present colonies reminds us of Polycitor (Eudistoma) olivaceus (VAN NAME) described by Tokioka from Iwayama Bay of the Palau Islands (1942, pp. 497-500), which is provided with up to 50-60 tentacles in contrast to 32 in the 
specimens from the West-Indies. The appearance of the present colonies resembles closely that of E. olivaceus from Palau (TokiokA, 1942, pl. IV, fig. 4). However, in addition to the differences in number of stigmata (up to 25 in a row in olivaceus) and in number of transverse muscles on the thorax (approximately 10 in olivaceus), already mentioned by Токіока (1967), the nature of habitus seems to differ significantly between the two. E. olivaceus from Palau was found generally attached to the erect roots of the mangrove, while the present colonies were found in the area not so much sheltered as the mangrove swamp.

\section{REFERENCES}

Slurter, G. P. (1900): Tunicaten aus dem Stillen Ozean. Zool. Jahrb., Syst., vol. 13, pp. 1-35, pls. 1-6. (1909): Die Tunicaten der Siboga-Expedition. II Abt. Die merosomen Ascidien. SibogaExped., Monogr. 56 b, 112 pp., 2 text-figs., 8 pls.

TokiokA, T. (1942): Ascidians found on the mangrove trees in Iwayama Bay, Palau. Palau Trop. Biol. Stat. Studies, vol. 2, no. 3, pp. 497-506, 2 text-figs., pl. 4.

(1967): Pacific Tunicata of the United States National Museum. U.S. Nat. Mus. Bull. 251, 247 pp., 105 text-figs.

Van Name, W. G. (1945): The North and South American ascidians. Bull. American Mus. Nat. Hist., vol. 84,476 pp., 327 text-figs., 31 pls. 